Number of article: 627

Received: November 14, 2019

Accepted: December 9, 2019

\title{
ENERGY HARVESTING USING PIEZOELECTRIC CERAMICS INCORPORATED IN A SHOE-SOLE
}

\author{
Franka Grazhdani, Maja Anačkova, Jovana Jovanova \\ Faculty of Mechanical Engineering, "Ss. Cyril and Methodius" University in Skopje, \\ P.O. Box 464, MK-1001 Skopje, Republic of North Macedonia \\ maja.anachkova@mf.edu.mk
}

\begin{abstract}
A b s t r a c t: Energy harvesting as a concept of "catching" the energy which is wasted due to inevitable processes is a very promising technology for energy collection and its transformation into a type of energy suitable to power wireless devices. Energy can be harvested by using different materials properties, such as piezoelectrics, in order to produce electricity when being exposed to mechanical vibrations. This paper focuses on achieving energy harvesting by one's walk or run, by incorporating shoes piezoelectric "smart soles" capable of transforming generated mechanical vibrations into electricity. Using the smallest amount of energy of one or more energy sources, accumulate that energy or even use it right away, is a new and effective way of dealing with the devices which need a constant power supply such as Wi-Fi modules, IoT devices or even personal gadgets. Therefore, the goal is to make energy harvesting devices easy to use by people in their everyday life, and yet inexpensive in order. In this paper, a model and design of a shoesole which uses the property of the piezoelectric materials to generate electric voltage as a result of mechanical vibrations is developed. The aspect of person's walk is used as mechanical stress that indicates vibrations in the sole which is collected in the piezoelectric placed in the shoe. The dynamics of movement of person's feet with different dynamic variables and other physical parameters that affect the process are discussed. An analytical model of the shoe-sole is built and experimental measurement results are explained. As proof of concept, a functional prototype is presented.
\end{abstract}

Key words: energy harvesting; piezoelectrics; "smart" shoe-sole

\section{ИСКОРИСТУВАЊЕ НА ЕНЕРГИЈА ДОБИЕНА СО ПОМОШ НА ПИЕЗОЕЛЕКТРИЧНА КЕРАМИЧКА ВЛОШКА ВО ЃОНОТ НА ЧЕВЛИТЕ}

А п с т р а к т: Општо е познато дека енергијата никогаш не се губи, таа само се трансформира од еден во друг облик. Концептот на „еnergy harvesting“ е да се „фати“ енергијата која е резултат на неизбежните процеси и да се претвори во енергија која ќе биде применлива. Еден начин на собирање на енергијата е употребата на различните својства на материјалите какви што се, на пример, пиезоелектриците кои прават трансформација на механичките вибрации во електрична енергија. Работата во овој труд е инспирирана од идејата за собирање енергија преку интегрирање пиезоелектрични „паметни влошки“ во чевли, кои се способни за трансформација на механичките вибрации од чекорење или трчање во електрична енергија. Користењето на најмала количина енергија од еден или повеќе извори, акумулирањето на таа енергија или дури и нејзиното директно користење, е нов и ефикасен начин за полнење на уредите на кои им е потребно постојано напојување, на пример Wi-Fi модулите, IоT уредите или модерните лични ситни предмети (,гаџети“). Целта е да се создадат уреди за собирање енергија лесни за употреба од страна на луѓето во нивниот секојдневен живот, а сепак евтини и достапни. Во овој труд е развиен модел и дизајн на ѓонот за чевли што го користи својството на пиезоелектричните материјали за производство на електричен напон како резултат на механички вибрации. Вибрациите генерирани од човечкиот од се користат како извор на енергија која се трансформира во електричен напон кој се собира во пиезоелектрикот поставен во чевелот. Во овој труд е дискутирана динамиката на движење при чекорење со различни динамички променливи и други физички параметри кои влијаат на процесот. Изграден е аналитички модел на ѓон за чевли и објаснети се резултатите од спроведеното експериментално мерење. Како доказ за концептот, на крајот е претставен и функционален прототип.

Клучни зборови: собирање на енергија; пиезоелектрици; „паметни“ ѓонови за обувки 


\section{INTRODUCTION}

Nowadays, everything around us is or eventually very soon will become electronic. If they already are, the devices we use might get updated with no wires at all, or with a lot of functions built. The more we substitute the regular devices with their electronic version, the more energy supply we shall need. Therefore, having a constant energy supply is an absolute need. Moreover, our way of living means mostly not being at home, thus electric energy onthe-move is also an important factor when dealing with supplying devices with electricity [1]. Power banks are a useful source, but also limited, since they themselves need to get charged [2]. That is why, energy elements that can generate voltage because of their physical characteristics is an interesting idea of having unlimited electric supply everywhere [3].

When a person walks or runs, they generate an amount of kinetic energy and by using a proper device, the energy can be transformed into electricity. This can be done by using piezoelectric transducer (Figure 1) [4]. Piezoelectrics are used to convert vibrations into electric charges thus used to measure some change. These specific piezo transducers are built with ceramic lead zirconate titanate PZT, or similar ceramics such as $\mathrm{PbTiO}_{3}, \mathrm{PbZrO}_{3}, \mathrm{PVDF}$ and PZT [5]. Zirconate titanate (PZT) is one of the most used material in this industry due to its cheap price and very good characteristics. The ceramics make it robust, reliable and able to work in high temperatures [6].

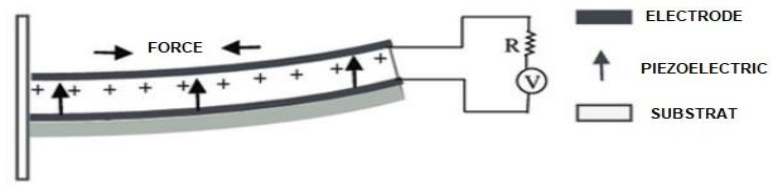

Fig. 1. Schematic of piezoelectric (flexible) energy harvester

In this paper, a design of a shoe-sole which uses the property of the piezoelectric materials to generate electric voltage as a result of mechanical vibrations is developed. The dynamics of movement of person's feet is described by different physical parameters and according to them, an analytical model of the shoe-sole has been created. Ultimately, a functional prototype has been built and the experimental measurement results are explained.

\section{DESIGN CONCEPT}

In the process of designing a shoe-sole, whether a "smart" or a regular one, the force distribution while walking should be analyzed. Naturally, people put their foot on the floor unevenly, meaning they strike with the heel first and the rest of the foot's surface follows. Most of the human population walks and runs by striking the heel first, meaning the heel of the foot is the first part to touch the surface of the ground. Therefore, the person's body mass distribution, presented in bodyweight per $\mathrm{cm}^{2}$, is not be equal as they walk. As an example, by hitting the ground a reaction force is applied to the foot, in magnitude of up to 3-5 times [7] the mass of the person. Whereas when the foot is almost completely placed on the floor, that force decreases to almost $0.5-1.5$ body weight per $\mathrm{cm}^{2}$. In Figure 2 below are shown the magnitudes of foot pressure distribution while walking. Naturally, our points of interest are the red areas, where the pressure has a highest value because is mandatory to care about the fact where the piezo ceramics are going to be placed exactly on the sole in order to generate maximum energy. Accordingly, piezo discs should be placed in the front of the sole where the big toe is, and normally, in the heel of the foot.

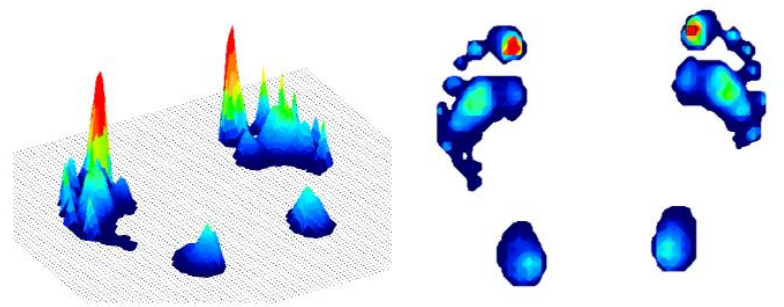

Fig. 2. Force distribution when walking [8]

Taking the shoe-sole of a standard EU 38 size number, the heel dimensions are as shown in Figure 3. This particular shoe-sole is taken from sneakers and simply measured, therefore, all further referring to sole will be about this one. The piezo transducer is in a form of a disc, where the piezo crystals are fixed on top of a metal base plate. Their weight is small, making the shoe-sole light and easy to wear.

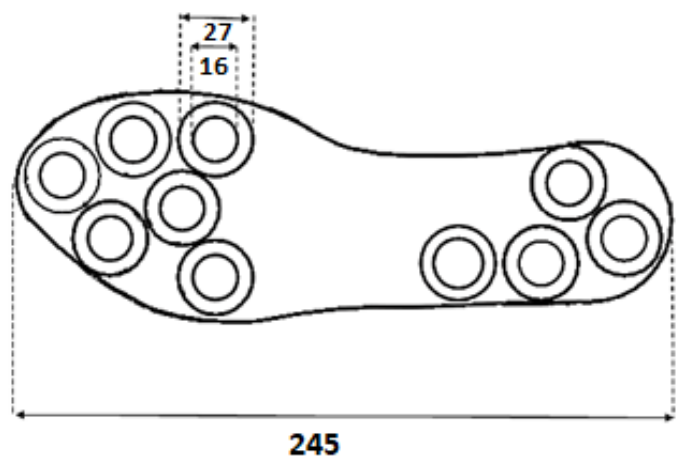

Fig. 3. Model of the sole and piezo discs with dimensions expressed in $\mathrm{mm}$ 
As the model shows, the sole has 10 piezo discs. The number of discs is chosen because of 2 key factors. Firstly, it was taken into account that only the heel and the finger part are most valuable when it comes to pressure, so discs are only placed in those parts in order to absorb as much energy as possible. Secondly, after having decided the location, the maximum number of piezo discs was discussed and taking in consideration the comfort of the shoe, it was concluded that the lower part (heel) should be consisted of 4 piezo discs, while the upper part of 6 piezo discs. Since the piezo ceramic material needs to deform in order to produce voltage, the sole is made from soft materials - cotton in order to avoid motion damping. Moreover, the original inner sole taken from the shoe, in this case a sneaker, will be placed above this smart sole. Thus, both surfaces above and below the piezo discs attached, are soft, not stopping the ceramics to deform. In Figure 4 are shown the CAD renders of the shoe-sole with the 10 piezoelectric discs.

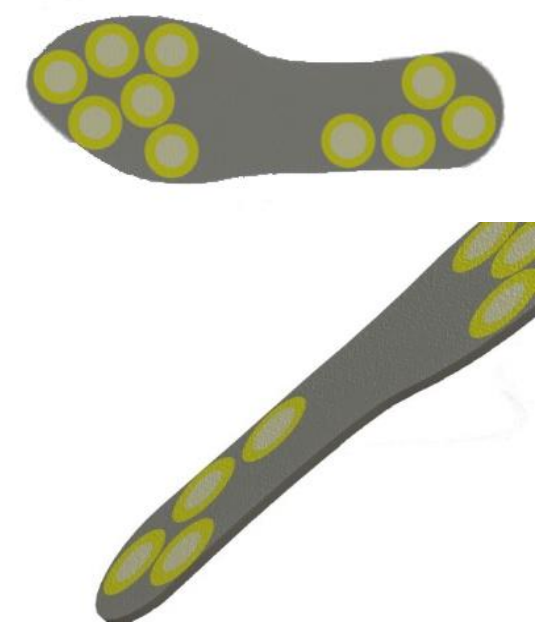

Fig. 4. CAD model of the sole

\section{SYSTEM FUNCTIONALITY}

After the explanation of the shoe-sole concept it is of high importance to explain the electric circuit in order to understand how to produce the electrical voltage from the mechanical vibrations from walking. Firstly, the piezo discs must be connected together. They are connected in parallel in order to achieve higher current at the same voltage, since one piezo element can produce up to $15 \mathrm{~V}$ alone when being stepped over (by a person in body weight 55$60 \mathrm{~kg}$ or above). These specific piezo discs produce electricity when exposed to vibrations, in this case person's walk, mechanically deform the crystal of the disc and thus produces alternating current.
Therefore, a Graetz rectifying bridge is connected in series in order to transform the current from $A C$ to DC. Since the AC current is a sine signal, when walking, the discs will not generate the same sine signal at the same time. This means that when the person's foot will be touching the ground only with the front part of the foot (that is when the foot is about to leave the floor at the end of each step), the front 6 discs will produce almost identical signals, with a maximum value for the voltage. In that moment, the signal from the heel discs will not be loaded thus leading to negative values for the voltage. Therefore, both amplitudes from the front of the sole and the heel will be annulated with each other, i.e. after summing the voltage values of the front and the back of the sole, the result will not be high, as it is required. To avoid this, both groups are separated according to their location in the sole. The front 6 are in one group, the other 4 in the heel are in the other group. Each group has individual rectifier, leading to total of two Graetz bridge rectifiers. After soldering the piezo elements together and adding the rectifiers, the voltage is measured. From the gained results it is shown that while walking, a high voltage is produced as given in Table 1 . The measurement was done by using a digital multimeter, on the heel part of the shoe-sole (only the 4 piezo elements in the heel were connected for this measurement) and the body weight of the person walking is 55 kilograms. Without using an energy storing unit, the voltage falls to 0 when the sole is not force loaded. Therefore, in order to keep the voltage constant, a capacitor is used. Two capacitors are used, the first with capacitance of $1 \mu \mathrm{F}$ and the other with $100 \mathrm{nF}$. After adding the capacitor to the circuit the results shown in Table 1 have been measured.

\section{T a b le 1}

\section{Voltage measured while walking with a frequency} of $1 \mathrm{~Hz}$, without and with using a capacitor

\begin{tabular}{ccc}
\hline \hline Steps & $\begin{array}{c}\text { Measured voltage in V } \\
\text { without using a capacitor }\end{array}$ & $\begin{array}{c}\text { Measured voltage in V } \\
\text { with using a capacitor }\end{array}$ \\
\hline 1 & 1.2 & 1.5 \\
2 & 8.9 & 2.9 \\
3 & 17.3 & 8.2 \\
4 & 13 & 5.3 \\
5 & 12.7 & 6.2 \\
6 & 16 & 6.6 \\
7 & 11.17 & 5.8 \\
8 & 17 & 7.1 \\
\hline \hline
\end{tabular}


If the device is not being charged and the person is walking, an excess amount of energy will be generated. Thus, if there is no battery or similar storage unit that energy will be wasted. Therefore, a Lipo 3.7 V rechargeable battery is connected within the system. The system now consists of: piezoelectric transducers, AC-DC converter, capacitor and a storage unit - battery (Figure 5).

The analytical model is created in Matlab Simulink/Simscape electrical and shows an electrical outlet pattern. The model is given in Figure 6.

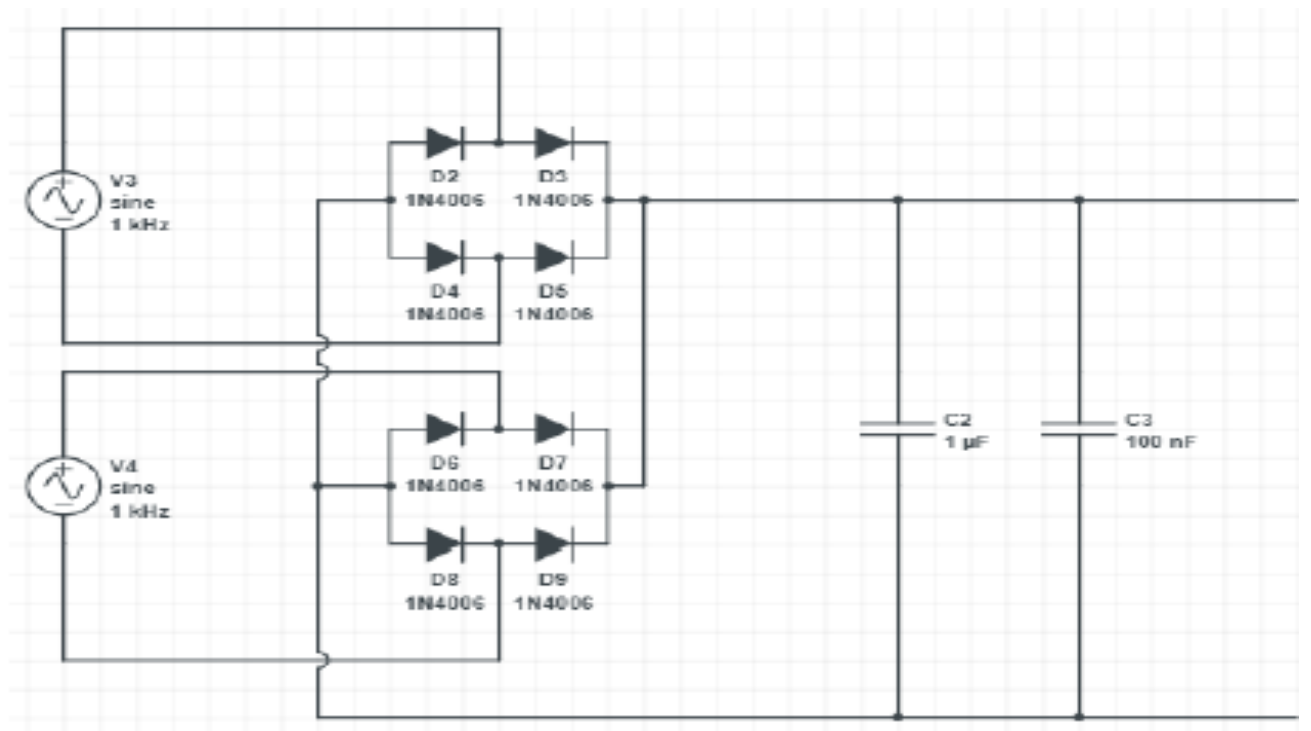

Fig. 5. Electric scheme of the components

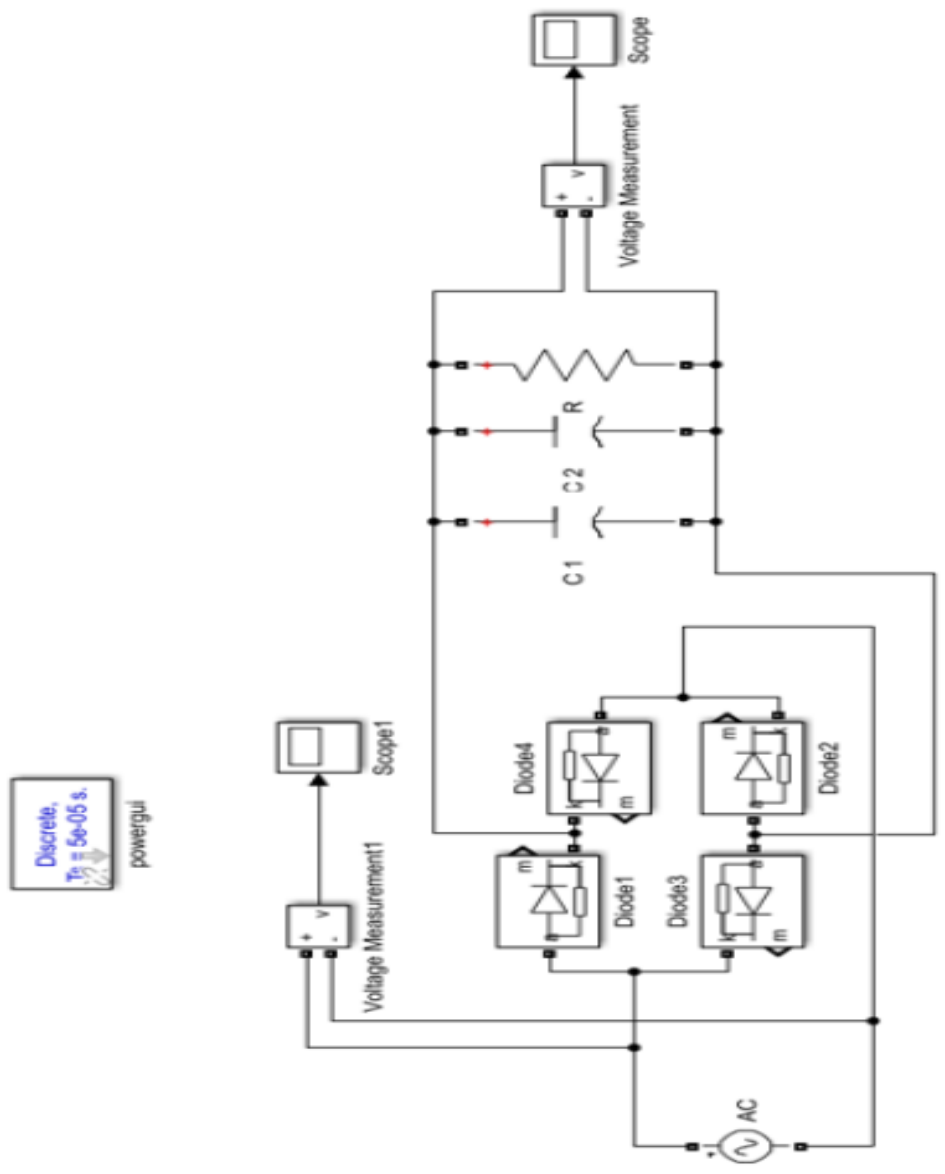

Fig. 6. Analytical model in Matlab/Simulink 
The results for the output voltage from the analytical Matlab/Simulink model are shown in Figure 7 and it can be noticed that the sine wave matches the curve obtained during the measurement. The ideal sine wave corresponds to the measurement below with a mass of $55 \mathrm{~kg}$, with a walking frequency of $2 \mathrm{~Hz}$ and a pad mounted on a rigid surface.

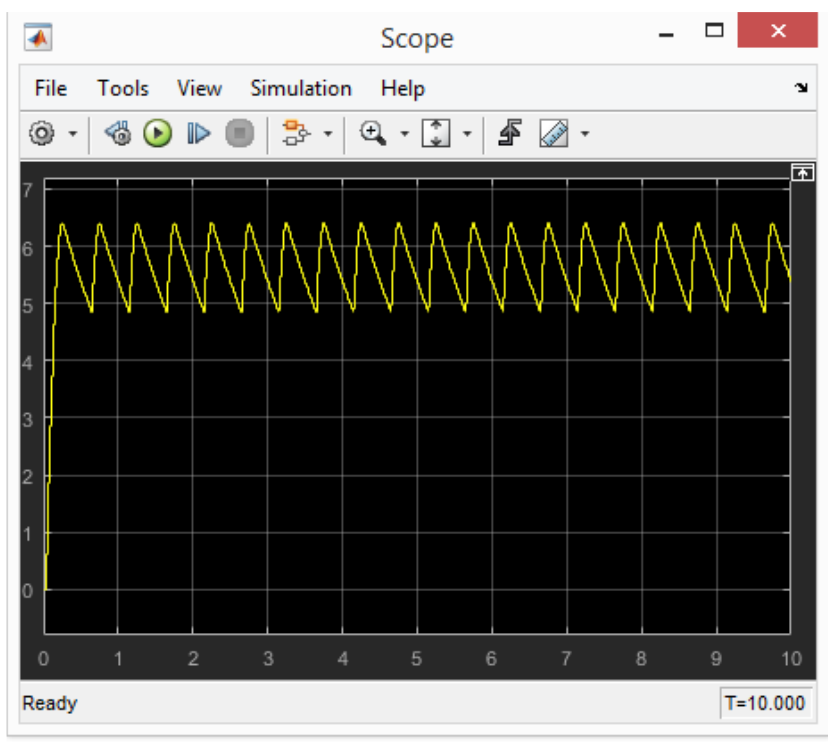

Fig. 7. Voltage characteristic from the Matlab/Simlunk model

The results show that the voltage reaches around $6.5 \mathrm{~V}$, which is also an ideal output voltage curve. They differ from the actual $1.5 \mathrm{~V}$ curve. However, this model includes only one disk with one rectifier.

\section{EXPERIMENTAL MODEL}

The experimental model consists of the shoesole and the electrical circuit explained in the previous section. The final piece needed to complete this energy harvesting device is the physical contact with the person, i.e. their body weight pressure when walking. That system as a whole is shown in Figure 8.

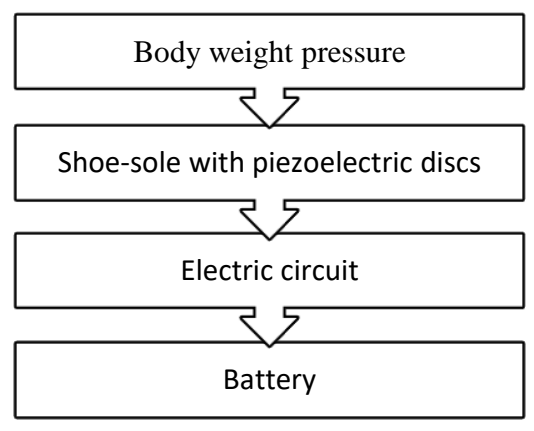

Fig. 8. System model
Because the smart sole is pressed when walking, the comfort is an important issue. Thus, the smart sole is a thin, cotton and flexible sole. In order not to cause any unpleasant feelings, the sole that is in the shoe itself is removed and the smart sole is placed instead. This way the shoe-sole is located below the smart one, increasing the flexibility when the discs are pressed and also the comfort. The output is a USB cable that can be inserted in a mobile phone in order to charge it. Figure 9 shows the final model of the shoe-sole.

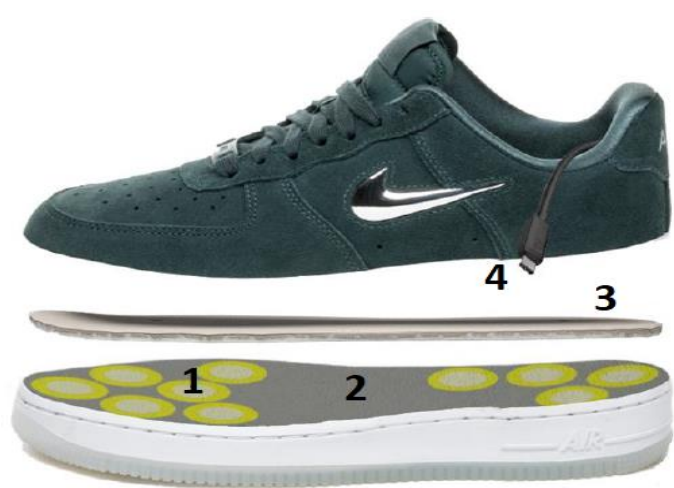

Fig. 9. Model showing the real sneaker prototype (1- piezoelectric discs, 2 - smart sole, 3 - shoe-sole, 4 - USB cable)

Many experiments have been conducted on the sole by using an oscilloscope. The Figure 10 shows the voltage signal in time while using only 1 capacitor of $100 \mathrm{nF}$. The measurement is made with a person of 55-60 kilograms, walking pace of 1 step per second (frequency of $1 \mathrm{~Hz}$ ), and the smart sole was placed on old shoe-sole and then placed on the floor. As seen from the results, the maximum voltage value is around 8.5 to $9 \mathrm{~V}$. Each peak is when the person steps on the ground. The voltage drop caused by the Graetz bridge is $0.57 \mathrm{~V}$.

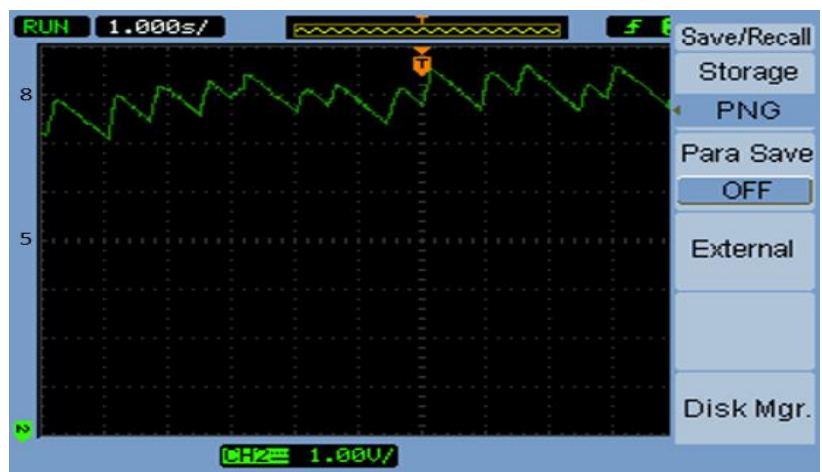

Fig. 10. Measurement by using only 1 capacitor

Since voltage falls around $2.5 \mathrm{~V}$ when the person lifts their foot, another capacitor is added. The 
results are shown in Figure 11. The figure shows a constant value for the voltage achieved by adding a second capacitor of $1 \mu \mathrm{F}$. The maximum values are around 7 to $9 \mathrm{~V}$. The measuring conditions are the same as the previous one.

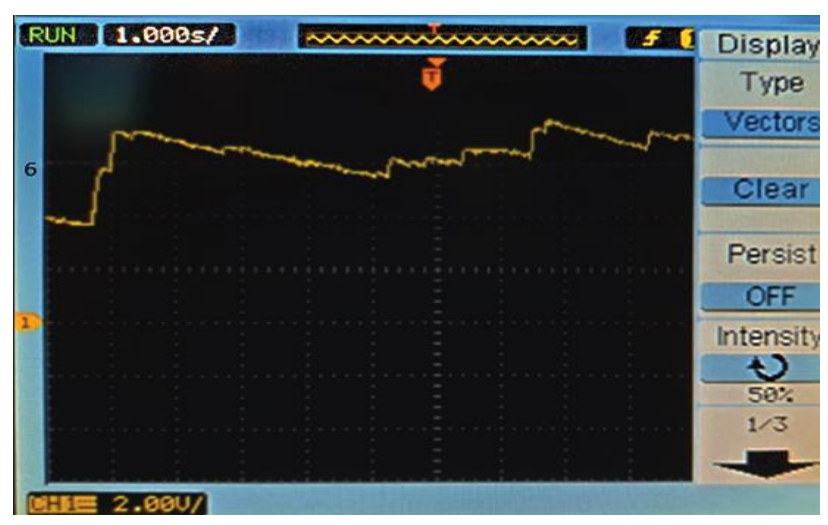

Fig. 11. Measurement using 2 capacitors

Both measurements were made on carpet, with a person walking with a $1 \mathrm{~Hz}$ frequency and mass of $55 \mathrm{~kg}$. A question of interest was whether these factors played a role on the voltage output, leading to more experiments being made. Another four measurements were made by changing the mass that is implemented on the shoe-sole given $5 \mathrm{~kg}, 22 \mathrm{~kg}$, $55 \mathrm{~kg}$ and $90 \mathrm{~kg}$. It was noticed that there is a difference in the output voltage between the small masses of $5 \mathrm{~kg}$, but those of $22 \mathrm{~kg}, 55 \mathrm{~kg}$ and $90 \mathrm{~kg}$ produced very similar voltage outputs. This means that the average body masses of $45 \mathrm{~kg}$ and above produce same amounts of voltage. As for the walking pace or frequency of walking, it was measured with different speeds, starting with slow walk of 1 step per 2 seconds, up to normal running of 3 steps per second.

\section{RESULTS}

The first set of measurements were performed with the help of Arduino. The measured values were displayed on a screen plotter on which the time axis (the horizontal axis) is wider than the horizontal axis of the oscilloscope where only 10 seconds of measured values are displayed. The measurement is done by analog reading directly from the Arduino. Since Arduino reads only analog values up to $5 \mathrm{~V}$, they are divided into 1024 parts, i.e. 210. Therefore, the vertical axis has values up to 1200 . The horizontal axis is displayed in milliseconds, where 10 divisions is equal to $1 \mathrm{~s}$. A total set of 3 measurements, with different masses, were performed in order to show the dependence of the mass on the obtained voltage. It can be seen in the Figure 12 that all voltage values above $5 \mathrm{~V}$ are not displayed but interpreted as a voltage duration of a few seconds. This measurement thus shows the voltage behavior with respect to the weight being pressed. All measurements were made with different magnitude of force due to different mass, same mode and direction of action, and same frequency of $1 \mathrm{~Hz}$ for that force to operate. Figure 12 shows the first measurement with $55 \mathrm{~kg}$ with 10 steps in total.

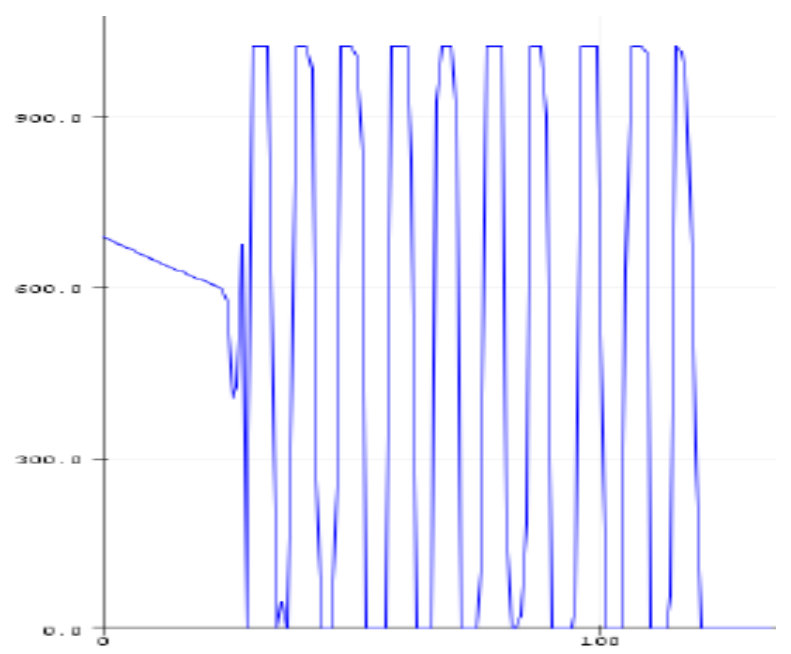

Fig. 12. Measurement of the dependence of human weight of $55 \mathrm{~kg}$ and voltage obtained using Arduino UNO

In Figure 13 the same measurement was made, but with a mass of $22 \mathrm{~kg}$. Same like the previous measurement, 10 steps were taken within $10 \mathrm{sec}-$ onds.

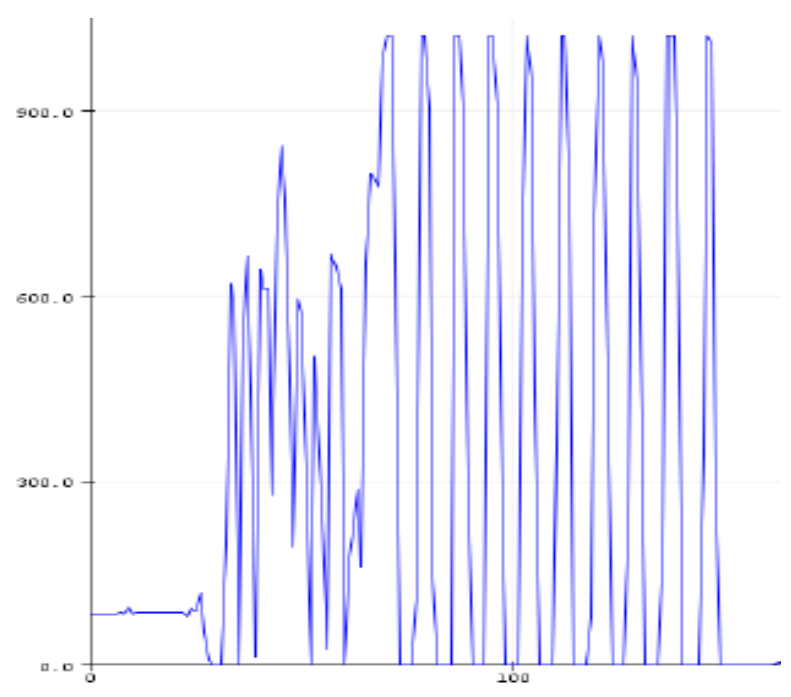

Fig. 13. Measurement of the dependence of human weight of $22 \mathrm{~kg}$ and voltage obtained using Arduino UNO

The third measurement is shown in Figure 14 with the lowest force, weighing $5 \mathrm{~kg}$. 


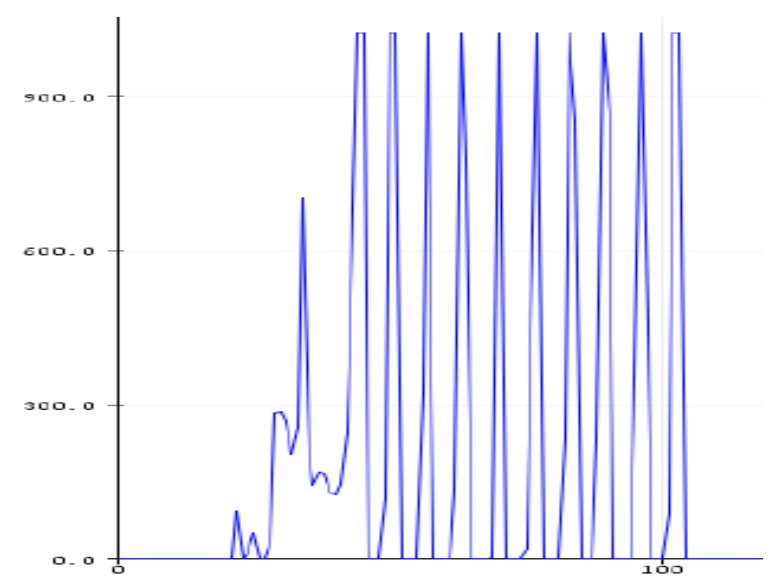

Fig. 14. Measurement of the dependence of human weight of $5 \mathrm{~kg}$ and voltage obtained using Arduino UNO

Comparing the graphs, it can be concluded that at $55 \mathrm{~kg}$ and $22 \mathrm{~kg}$ voltage values above $5 \mathrm{~V}$ are reached. The graphs are similar, but the difference is in the maximum values obtained, so the following measurements are made on an oscilloscope. The graphs above explain the fact that piezo discs generate more deformation voltage and can be obtained with a smaller mass (Figure 12) which is twice the mass and has a similar graph as Figure 13. This means that average human weights get the same voltage values if the frequency is the same. The additional impact of the mass will be important when using capacitors, which is explained below.

The voltage output depends on the intensity of the vibration applied, as well as on the frequency of walking. Therefore, the battery can be charged faster by running instead of walking and the average voltage output while running is $16 \mathrm{~V}$. In Table 2 are given the different average voltage outputs while walking.

\section{T a b le 2}

Average voltage outputs when walking with different pace

\begin{tabular}{cc}
\hline \hline Walking frequency (step/second) & $\begin{array}{c}\text { Voltage } \\
\text { (V) }\end{array}$ \\
\hline 0.5 & $4 \div 5$ \\
1 & $6 \div 7$ \\
2 & $8 \div 10$ \\
Running frequency (step/second) & \\
3 & 15 \\
\hline \hline
\end{tabular}

It is natural that the higher the frequency the higher the voltage output. According to the experimental measurements conducted on a $50 \mathrm{~kg}$ body weight person, the voltage output while running with a frequency of 3 steps/second is $30 \%$ percent higher than the output voltage generated person walking with a frequency of 1 step/second. However, this voltage is needed for the storing unit - battery. The third factor which is the most important for the output voltage is the elasticity of the surface below the smart sole which directly affects the discs deformability. The comparison between different surfaces is shown on the figures below. The signal given in Figure 15 is when the walking pace is $1 \mathrm{~Hz}$, and the surface (carpet). As seen below, the red arrows indicate each step made and the output is higher than the expected. This means that increasing the surface's elasticity leads to increase in the voltage output. In this measurement the average voltage is $10 \mathrm{~V}$.

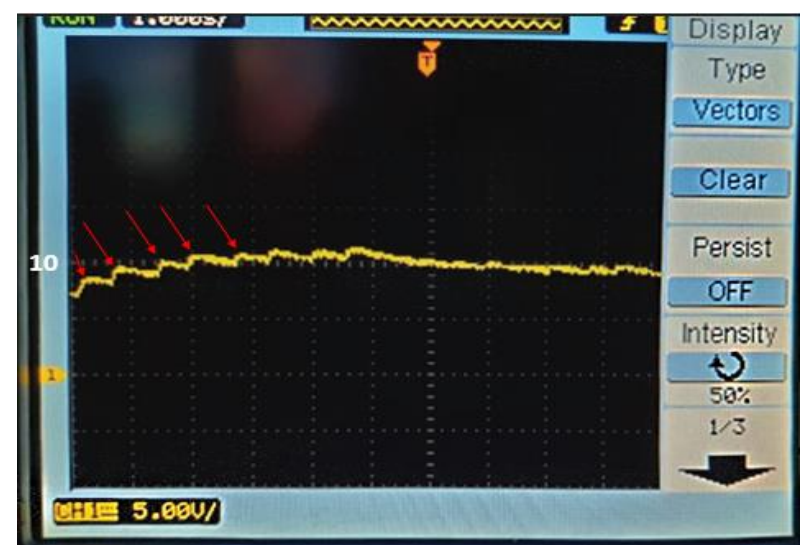

Fig. 15:. Measurement results when the smart sole is placed on a softer more elastic surface

Figure 16 shows measurement results provided when placing the sole on rubber surface. The walking pace is around $1.5-2 \mathrm{~Hz}$. The results show the highest measured voltage is achieving values of $20-$ $21 \mathrm{~V}$. This is almost twice as the same speed but measured on a rigid surface.

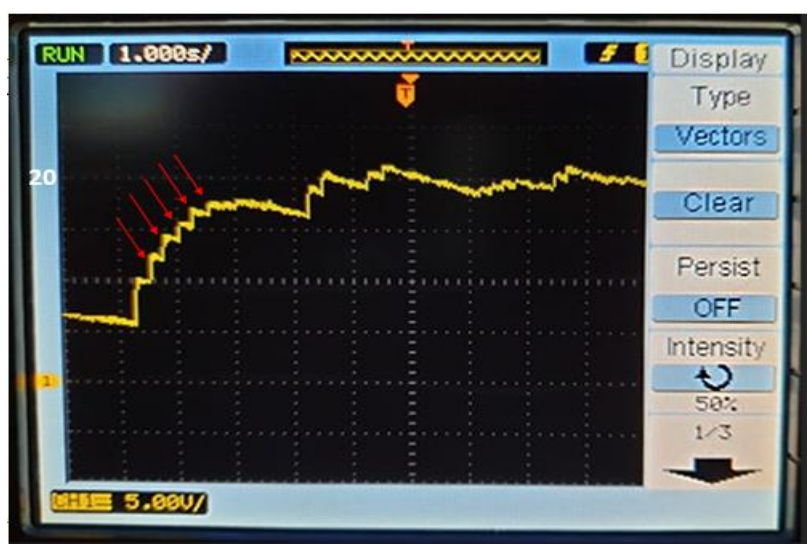

Fig. 16. Measurements results when the sole is placed on a very elastic rubber surface 
After measuring, it has been shown that the sneaker that was used for placing this sole is more elastic than the floor but less than the rubber, since the output voltage is between $7 \mathrm{~V}$ and $9 \mathrm{~V}$ when walking with $1 \mathrm{~Hz}$ frequency.

\section{CONCLUSION}

In this paper, a "smart" sole model incorporated in a shoe through the implementation of piezoelectric devices that detect human walking in the form of a deformation that generates voltage was developed. The aim was to achieve the conversion of mechanical energy from the human walking into electricity. Furthermore, electricity was used to charge the mobile phone, thus proving the application aspect of this thesis. The relevance of certain external influences and parameters and how they influence the effectiveness of using such a system in daily use were also discussed. According to all the measurements and research done in this work, it was found that at all human weights and at the same frequency of walking almost the same voltage is obtained. An important parameter is the dynamic of walking, as it depends on how hard the ground is hit and the pad itself. Another factor that is directly related to the size of the voltage is the type of footwear, which, if tighter, does not allow the pad to be deformed significantly. So, with sneakers (because they are more elastic) you would get more voltage, while with tight shoes less. The results show the highest measured voltage is achieving values of 20-21 V which is confirmed by the results given in [4] where the heelplaced PVDF film produced voltages of roughly $30 \mathrm{~V}$, while the forefoot-placed PVDF film gave lower response values approaching 22 V. In Figure 8 in [4] is given the dependence of the frequency of walking and the generated voltage from which can be concluded that for $1 \mathrm{~Hz}$ frequency of walking, the generated voltage is approximately $6 \mathrm{~V}$. The same conclusion can be outlined from Table 2 in this paper, but here, series of measurements and analysis for different frequencies were conducted. However, due to the battery voltage of $3.7 \mathrm{~V}$, enough power is generated on any substrate to charge the battery. This means that whether it is a trainer or a shoe, the voltage required to charge the battery, which is $4 \mathrm{~V}$, is achieved. So, in any case, the battery would charge, but with a different charging speed. The next conclu- sion that is important for effective charging is the speed of walking. Although it was previously concluded that both slow walking and fast walking exceed the walking voltage and that it is not strictly related to human mass, it is important to note that faster walking or running would have a faster battery charge. Battery is an important element of the circuit because it powers the electronic device and recharges it. In this case the battery is low, so charging the device itself is slow. This is due to the small values obtained for electricity. A recommendation for future work would be to increase the output current and the capacity of the battery. From the similarities in the results provided in [4] and in this paper, can be concluded that the energy harvesting devices such as piezoelectric are suitable devices to be integrated in powering some low wearable sensors, such as activity trackers, blood pressure sensors, sensors for healthcare etc.

\section{REFERENCES}

[1] El-Sayed, A. R., Tai, K., Biglarbegian, M., Mahmud, S.: A survey on recent energy harvesting mechanisms. In: 2016 IEEE Canadian Conference on Electrical and Computer Engineering (CCECE), IEEE. May 2016, pp. 1-5.

[2] Gupta, A., Sharma, A.: Piezoelectric energy harvesting via shoe-sole. International Journal of New Technology and Research, Vol. 1, No. 6 (Oct. 2015)

[3] Frontoni, E., Mancini, A., Zingaretti, P., Gatto, A.: Energy harvesting for smart shoes: A real life application. In: ASME 2013 International Design Engineering Technical Conferences and Computers and Information in Engineering Conference. American Society of Mechanical Engineers Digital Collection (February 2013).

[4] Zhao, J., You, Z.: A shoe-embedded piezoelectric energy harvester for wearable sensors. Sensors, 14 (7), pp. 12497 12510 (2014).

[5] Hillyard, D. C., Thompson, J., Kosinski, A. and McNabb, P.: Development of an Energy-Harvesting Shoe. 2014.

[6] Lee, B. C., Rahman, M. A., Hyun, S. H., Chung, G. S... Low frequency driven electromagnetic energy harvester for selfpowered system. Smart Materials and Structures, 21 (12), p. 12524 (2012).

[7] Othman, A.: Modeling of piezoelectric energy harvesting system embedded in soldier's boot using Matlab/Simulink. In: 2017 International Conference on Military Technologies (ICMT), Brno, IEEE, May 2017, pp. 787-792.

[8] Nandikolla, V. K., Bochen, R., Meza, S., Garcia, A: Experimental gait analysis to study stress distribution of the human foot. Journal of Medical Engineering, 2017. DOI: $10.1155 / 2017 / 3432074$, 